\title{
PENERAPAN PSAK 71 PADA PERUSAHAAN PENJAMINAN KREDIT: TELAAH TEORI INSTITUSIONAL
}

\author{
Lestari Kurniawati $^{1}$ \\ 1) lestari.kurniawati@pknstan.ac.id, Politeknik Keuangan Negara STAN
}

\begin{abstract}
DSAK IAI stated that PSAK 71 will be effective starting January 1, 2020. However, several studies have shown that several business entities have not implemented PSAK 71. Banking and financial institutions are one of the sectors most affected by the implementation of PSAK 71. Credit guarantee companies are one of the industries in Indonesia. This sector has a role in expanding access to credit for MSMEs. However, the limited capacity of credit guarantee companies can be an obstacle to the implementation of PSAK 71. This study uses institutional theory to analyze factors that influence the decision to implement PSAK 71. The results show that 15 companies that have not implemented PSAK 71 are constrained by the development of the ECL model and infrastructure systems. These two components act artifacts (material carriers) within the framework of institutional theory. Meanwhile, the decision taken by 15 companies not to implement PSAK 71 in 2020 is a wait and see attitude for the issuance of OJK rules. This decision can be categorized as mimetic isomorphism. On the other hand, three companies that decided to implement PSAK 71 in 2020 can be identified as having a professional attitude (normative isomorphism). Meanwhile, nine other companies that are still in the preparation stage for implementation can be categorized as changes that are coercive isomorphism. In preparation for the implementation of PSAK 71, the role of the community has been present but is still limited. The role of the community in bridging discussions and relationships between implementing actors (relational system in material carriers) is constrained due to waiting for the issuance of OJK regulations.
\end{abstract}

Keywords : Institutional theory, credit guarantee companies, ECL, PSAK 71

\begin{abstract}
Abstrak
DSAK IAI menetapkan PSAK 71 efektif mulai berlaku sejak 1 Januari 2020. Namun demikian beberapa penelitian menunjukkan beberapa entitas bisnis belum menerapkan PSAK 71. Perbankan dan lembaga keuangan merupakan salah satu sektor yang paling terdampak atas penerapan PSAK 71. Perusahaan penjaminan kredit sebagai salah satu industri di sektor ini yang memiliki peran untuk memperluas akses kredit bagi UMKM. Namun demikian keterbatasan kapasitas dari perusahaan penjaminan kredit bisa menjadi penghambat penerapan PSAK 71. Penelitian ini menggunakan teori institusional untuk melakukan analisis factor yang berpengaruh terhadap keputusan penerapan PSAK 71. Hasil penelitian menunjukkan 15 perusahan yang belum menerapkan PSAK 71 terkendala oleh pengembangan model ecl untuk menentukan Cadangan Kerugian Penurunan Nilai serta sistem infrastruktur. Dua komponen ini berperan sebagai artifak (material carrier) dalam kerangka teori institusional. Sementara itu keputusan yang diambil oleh 15 perusahaan untuk belum menerapkan PSAK 71 pada tahun 2020 merupakan sikap wait and see atas terbitnya aturan OJK. Keputusan ini bisa dikategorikan sebagai mimetic isomorphism. Di sisi lain, tiga perusahaan yang memutuskan untuk menerapkan PSAK 71 pada tahun 2020 dapat diidentifikasi sebagai sikap professional (normative isomorphism). Sementara sembilan perusahaan lain yang masih dalam tahap persiapan penerapan dapat dikategorikan sebagai perubahan yang bersifat coercive isomorphism. Dalam persiapan penerapan PSAK 71 ini peran komunitas telah hadir namun masih terbatas. Peran komunitas dalam menjembatani diskusi dan hubungan antar aktor pelaksana (relational system dalam material carriers) terkendala karena menunggu terbitnya aturan OJK.
\end{abstract}

Kata Kunci : Teori Institusional, perusahaan penjaminan kredit, PSAK 71

\section{PENDAHULUAN}

Dewan Standar Akuntansi Keuangan Ikatan Akuntan Indonesia (DSAK IAI) merilis Pernyataan Standar Akuntansi Keuangan (PSAK) 71 Instrumen Keuangan. DSAK IAI telah menerbitkan PSAK 71 pada tahun 2017 namun implementasi baru diwajibkan per 1 Januari 2020. Perubahan penting yang diatur dalam PSAK 71 sebagai pengganti PSAK 55 adalah pengklasifikasian asset keuangan dan pencadangan atas penurunan nilai asset keuangan baik berupa piutang, pinjaman atau kredit.

Ulasan kontan.co.id (2019) mengungkapkan perubahan mendasar yang diatur dalam PSAK 71 adalah adanya pencadangan dilakukan sejak awal periode kredit dan dihitung dengan mempertimbangkan aspek masa lalu, kini dan proyeksi di masa mendatang. Dalam pencatatan 


\section{JURNALKU}

Volume 1 No. 3, September 2021

ini, entitas harus mengidentifikasi status kredit apakah lancar (performing), ragu-ragu (underperforming) ataupun macet (non performing). Model perhitungan ini berpotensi meningkatkan nilai pencadangan kredit atas piutang tak tertagih. Hal ini sejalan dengan hasil penelitian Suroso (2017) yang menyatakan bahwa berdasarkan hasil simulasi penerapan PSAK 71 dapat berakibat pada kenaikan Cadangan Kerugian Penurunan Nilai (CKPN) dan Capital Adequacy Ratio (CAR). Lebih lanjut Suroso (2017) juga menyatakan bahwa penerapan PSAK 71 bermanfaat dalam menyajikan informasi relevan dan berguna bagi pengguna laporan keuangan untuk melakukan penilaian terhadap jumlah, waktu dan ketidakpastian arus kas masa depan entitas.

Hal senada diungkapkan Ketua Umum Institut Akuntan Publik Indonesia (IAPI), tirto.id (2019) bahwa penerapan PSAK 71 akan meningkatkan CKPN. Peningkatan CKPN dapat berdampak pada turunnya CAR dan menekan bottom line (laba/rugi bersih) perbankan. Lebih lanjut Ketua Umum IAPI menyatakan emiten yang terdampak atas penerapan PSAK 71 adalah emiten perbankan dan juga emiten yang memiliki investasi di sektor keuangan seperti pembelian obligasi.

Salah satu entitas yang memiliki investasi di sektor keuangan adalah perusahaan penjaminan. Peraturan Otoritas Jasa Keuangan Nomor 6/POJK.05/2014 menyatakan perusahaan penjaminan merupakan badan hukum yang bergerak di bidang keuangan dengan kegiatan usaha melakukan penjaminan. Kegiatan usaha perusahaan penjaminan adalah melakukan penjaminan dengan menanggung pembayaran atas kewajiban finansial Terjamin kepada Penerima Jaminan apabila Terjamin tidak dapat memenuhi kewajibannya berdasarkan perjanjian yang telah disepakati. Di sisi lain, dalam rangka menunjang operasional kegiatannya, perusahaan penjaminan melakukan investasi dalam berbagai bentuk asset keuangan seperti surat berharga, surat berharga negara dan obligasi. Dengan demikian perusahaan penjaminan juga merupakan salah satu entitas bisnis yang akan terdampak atas penerapan PSAK 71 .

Berdasarkan data yang dirilis Otoritas Jasa Keuangan (OJK), per 30 Juni 2020 terdapat 21 Lembaga Penjamin di Indonesia yang terdaftar di OJK. Lembaga penjamin tersebut terdiri dari 1 Badan Usaha Milik Negara (BUMN), 2 Perusahaan Penjaminan Kredit Swasta, dan 18 Perusahaan Penjaminan Kredit Daerah (Jamkrida). Perum Jamkrindo merupakan Lembaga penjamin yang berstatus sebagai BUMN. Kontan.co.id (2019a) dalam beritanya merilis pernyataan Perum Jamkrindo atas pengaruh penerapan PSAK 71 bagi kinerja keuangan perusahaan. Dalam berita tersebut, Direktur Utama Perum Jamkrindo menyatakan penerapan PSAK 71 akan meningkatkan beban penyisihan nilai cadangan dalam nilai yang cukup besar. Menindaklanjuti hal ini, Perum Jamkrindo diharuskan untuk merevisi capaian target laba rugi yang telah disusun sebelumnya.

Potensi dampak penerapan PSAK 71 terhadap perusahaan penjaminan juga diberitakan oleh Bisnis.com (2021). Dalam beritanya Bisnis.com (2020) menyajikan pernyataan PT Pemeringkat Efek Indonesia (PT Pefindo) yang menilai bahwa bisnis penjaminan akan menerima dampak moderat dari pemberlakuan pembatasan aktivitas masyarakat pada masa pandemic COVID-19. Kondisi pandemic COVID-19 dapat memicu pencairan pinjaman baru oleh bank dan perusahaan pembiayaan. Namun demikian, pada saat yang sama aktivitas klaim dapat meningkat sejalan dengan kondisi ekonomi makro yang melemah.

Perusahaan penjaminan kredit merupakan mandat atas kebijakan Pemerintah untuk meningkatkan kemampuan pendanaan dan memperlancar kegiatan dunia usaha guna meningkatkan pertumbuhan ekonomi nasional. OJK menerjemahkan tugas perusahaan penjamin kredit sebagai jembatan akses UMKM kepada bank/lembaga keuangan, terutama UMKM yang feasible namun belum bankable. UMKM ini secara entitas bisnis bagus namun memiliki keterbatasan modal dan sulit mengakses sumber pembiayaan karena tidak mampu menyediakan agunan. Dalam prakteknya, Perusahaan Penjaminan Kredit melakukan 


\section{JURNALKU}

Volume 1 No. 3, September 2021

penjaminan atas pemenuhan kewajiban finansial UMKM sebagai penerima kredit dari bank/lembaga keuangan (OJK.go.id, 2020).

Berdasarkan data Tahun 2019 yang dirilis oleh Kementerian Koperasi dan Usaha Kecil dan Menengah, jumlah UMKM di Indonesia adalah 65.465.497. Jumlah tersebut mengambil porsi $99,99 \%$ jumlah entitas usaha di Indonesia. Pada tahun 2019, UMKM juga berhasil mempekerjakan sejumlah 119.562.843 tenaga kerja atau mencapai 97\% dari jumlah tenaga kerja. Kontribusi UMKM terhadap PDB Indonesia juga cukup signifikan yakni sebesar $60,51 \%$. Namun demikian, UMKM merupakan entitas usaha yang rawan mengalami kebangkrutan meski tidak sedikit juga UMKM baru yang bermunculan. Hal ini tidak terlepas dari sifat UMKM yang hanya membutuhkan modal yang relative kecil dalam pendiriannya. Namun demikian modal yang relative kecil ini sekaligus menjadi ancaman bagi UMKM untuk mengembangkan usaha ataupun sekedar mempertahankan kelangsungan usahanya.

Hal ini sebagaimana diberitakan Viva.co.id (2021) yang menyatakan pandemi COVID19 memberikan dampak besar bagi UMKM. Pendapatan UMKM mengalami penurunan drastis akibat adanya kebijakan Pembatasan Sosial Berskala Besar (PSBB). Kebijakan ini berdampak pada terhambatnya aktivitas perdagangan dan tidak sedikit UMKM yang terpaksa menutup usahanya karena tidak bisa bertahan di tengah pandemi COVID 19. Penutupan usaha yang dilakukan UMKM sebagian besar terjadi karena lemahnya modal dan tidak adanya akses pembiayan ke bank/lembaga keuangan. Akses pembiayaan kepada bank/lembaga keuangan pada umumnya membutuhkan agunan berupa asset yang dimiliki UMKM. Hadirnya perusahaan penjamin kredit dapat membuka akses pembiayaan bagi UMKM terutama UMKM yang feasible namun tidak bankable. Dengan demikian diharapkan penutupan usaha UMKM yang kinerjanya bagus tidak terjadi sehingga dapat mendukung pertumbuhan perekonomian nasional.

Peran perusahaan penjaminan kredit atas perluasan kredit bagi UMKM sangat signifikan. Namun sebagai sebuah entitas bisnis, perusahaan penjaminan kredit juga harus dapat menyajikan laporan keuangan sesuai dengan standar. Dukungan serta jaminan Pemerintah terhadap perusahaan penjaminan kredit tidak serta merta menghilangkan kewajibannya sebagai entitas bisnis dalam mematuhi ketentuan yang berlaku. PSAK 71 seharusnya diterapkan oleh seluruh entitas bisnis terhitung sejak 1 Januari 2021. Namun demikian, mempertimbangkan kompleksitas penerapan PSAK 71 ada potensi tertundanya penerapan PSAK 71. Perusahaan penjaminan kredit sebagai salah satu lembaga keuangan yang berpotensi terdampak atas penerapan PSAK 71 sangat menarik untuk dikaji. Pada satu sisi, perusahaan penjaminan kredit merupakan kepanjangan tangan pemerintah dalam memperluas akses kredit bagi UMKM. Namun di sisi lain, beberapa perusahaan penjaminan kredit memiliki kapasitas yang terbatas sehingga berpotensi mengalami kesulitan dalam penerapan PSAK 71.

Penelitian ini berupaya untuk menjawab pertanyaan penelitian tentang faktor-faktor apa yang mempengaruhi perusahaan penjaminan kredit untuk menerapkan/tidak menerapkan PSAK 71 pada tahun 2020. Penelitian ini menggunakan kerangka teori institusional untuk melihat faktor-faktor yang mempengaruhi perusahaan untuk menerapkan PSAK 71. Ruang lingkup penelitian ini dibatasi pada perusahaan penjaminan kredit konvensional di Indonesia dengan periode penelitian pada tahun 2020. Penelitian ini bertujuan untuk memberikan gambaran kesiapan dan hambatan-hambatan yang dihadapi perusahaan penjaminan dalam upayanya untuk menerapkan PSAK 71. Hasil penelitian ini diharapkan dapat memberi masukan kepada dewan standar dan pemerintah tentang kendala penerapan PSAK 71 pada perusahaan penjaminan kredit. Bagi perusahaan penjaminan kredit, penelitian ini diharapkan dapat memberikan gambaran praktik kesiapan perusahaan penjaminan kredit konvensional di Indonesia dalam menerapkan PSAK 71. 


\section{JURNALKU}

Volume 1 No. 3, September 2021

\section{KAJIAN PUSTAKA}

\section{Perusahaan Penjamin Kredit: Upaya Perluasan Akses Kredit bagi UMKM}

Perusahaan Penjaminan Kredit dibentuk sebagai implementasi kebijakan pemerintah untuk meningkatkan kemampuan pendanaan dan memperlancar kegiatan dunia usaha guna meningkatkan pertumbuhan ekonomi nasional. Pembentukan Lembaga Penjaminan Kredit Koperasi (LJKK) pada tahun 1970-an merupakan Langkah awal Pemerintah mengembangkan program penjaminan kredit. LJKK bertugas untuk membantu koperasi dalam penyediaan agunan yang merupakan persyaratan dalam perolehan kredit dari bank. Pada tahun 1981, LJKK kemudian berubah menjadi Perusahaan Umum Pengembangan Koperasi (Perum PKK) yang merupakan Badan Usaha Milik Negara (BUMN). Selanjutnya berdasar Peraturan Pemerintah (PP) Nomor 95 Tanggal 7 November 2000, Perum PKK berubah menjadi Perum Sarana Pembangunan Usaha (Perum SPU). Perubahan ini membawa konsekuensi perluasan tugas dan fungsi yaitu melaksanakan penjaminan kredit kepada Koperasi Usaha Kecil dan Menengah yang mengajukan kredit ke bank/ Lembaga keuangan. Pada Tahun 2008 Pemerintah kembali mengubah Perum SPU menjadi Perum Jaminan Kredit Indonesia (Jamkrindo). Perum Jamkrindo bertugas melaksanakan penjaminan kredit bagi Usaha Mikro, Kecil, Menengah dan Koperasi (UMKMK). Selain itu Perum Jamkrindo juga dapat melaksanakan kegiatan penjaminan kredit perorangan, jasa konsultasi dan jasa manajemen kepada UMKMK (Antara, 2008). Selanjutnya pada tahun 2020, Perum Jamkrindo bertransformasi menjadi PT Jamkrindo (Persero) dan berubah lagi menjadi PT Jamkrindo. Ruangenergi.com (2020) menyatakan perubahan terakhir dilakukan karena PT Jamkrindo masuk ke dalam holding Indonesia Finansial Group (IFG) dengan induk holding PT Bahana Pembinaan Usaha Indonesia (Persero)

Tekad Pemerintah untuk memberi dukungan atas pertumbuhan dan perkembangan UMKM Kembali diwujudkan melalui pembentukan Perusahaan Penjamin Kredit Daerah (PPKD). Pembentukan PPKD dimaksudkan agar dapat memperluas akses pembiayaan kredit UMKM di perbankan. Pembentukan PPKD akan lebih mendekatkan lembaga penjaminan kepada UMKM yang tersebar di berbagai daerah. Berdasarkan data (Setkab, 2014), terdapat 16 propnsi yang telah membentuk PPKD, yaitu: 1) Provinsi Jawa Timur (2009), 2) Propinsi Bali (2010), 3) Propinsi Riau (2012), 4) Propinsi NTB (2012, 5) Propinsi Jawa Barat (2013), 6) Propinsi Sumatera Barat (2013), 7) Propinsi Kalimantan Selatan (2014), 8) Propinsi Sumatera Selatan (2014), 9) Propinsi Bangka Belitung, 10) Propinsi Kalimnatan Timur, 11) Propinsi Kalimantan Tengah, 12) Propinsi Banten, 13) Propinsi Kalimantan Barat, 14) Propinsi Jawa Tengeh, 15) Propinsi D.I. Yogyakarta, 16) Propinsi Sumatera Utara. Di sisi lain, PT Jamkrindo juga telah tumbuh dan memiliki 9 kantor wilayah, 56 kantor cabang dan 16 kantor unit pelayanan. Perluasan lembaga penjamin kredit diharapkan dapat membantu UMKM untuk dapat mengakses pembiayaan perbankan.

Dalam upaya untuk memberikan dukungan dan pengaturan yang jelas atas lembaga penjaminan kredit, pemerintah menetapkan Peraturan Menteri Keuangan (PMK) Nomor 222/PMK.010/2008 tentang Perusahaan Penjaminan Kredit dan Perusahaan Penjaminan Ulang Kredit. Aturan ini kemudian telah diubah terakhir kali melalui PMK Nomor 99/PMK.010/2011. Penjaminan kredit dalam peraturan ini didefinisikan sebagai kegiatan pemberian jaminan atas pemenuhan kewajiban finansial terjamin. Lebih lanjut disampaikan terjamin merupakan pihak yang telah memperoleh kredit dan/atau pembiayaan dari lembaga keuangan yang dijamin penjamin baik perorangan, badan usaha, perseroan terbatas, unit usaha suatu yayasan, koperasi dan usaha mikro, kecil dan menengah (UMKM). Dalam kegiatan usaha penjaminan kredit tersebut, perusahaan penjaminan kredit menerima Imbal Jasa Penjaminan (IJP) dari pihak terjamin. Di sisi lain, bank/lembaga keuangan sebagai penerima jaminan dapat mengajukan klaim yaitu tuntutan pembayaran akibat terjamin tidak dapat memenuhi kewajiban sesuai dengan perjanjian. 


\section{JURNALKU}

Volume 1 No. 3, September 2021

Pada sisi lain, dalam mengelola keuangannya, perusahaan penjaminan kredit melakukan berbagai investasi baik berupa saham maupun surat berharga lainnya. Namun demikian perusahaan penjaminan kredit memiliki batasan yang ditetapkan pemerintah. Pembatasan investasi perusahaan penjamin kredit diatur dalam Pasal 4A PMK Nomor 99/PMK.010/2011. Dalam pasal tersebut dinyatakan bahwa perusahaan penjamin hanya dapat melakukan investasi dalam bentuk: (a) deposito pada bank umum; (b) surat berharga negara dan/atau surat berharga syariah negara; (c) surat berharga dan/atau surat berharga syariah yang diterbitkan oleh Bank Indonesia; (d) obligasi korporasi dan/atau sukuk korporasi yang masuk peringkat investasi (investment grade); (e) saham yang tercatat di bursa efek Indonesia; (f) reksadana dan/atau reksadana Syariah; dan/atau (g) penyertaan langsung pada penjamin ulang.

Selain mengatur/membatasi jenis investasi, pemerintah juga melakukan pembatasan besaran atau proporsi investasi pada masing-masing jenis investasi tersebut. Peraturan Otoritas Jasa Keuangan (POJK) Nomor 6/POJK.05/2014 Pasal 7 ayat (3) memberikan batasan-batasan atas besaran investasi dari masing-masing jenis investasi yang diizinkan. Batasan-batasan yang ditetapkan pemerintah atas investasi perusahaan penjaminan adalah: (a) Investasi dalam bentuk deposito pada setiap bank umum ditetapkan paling tinggi $25 \%$ dari jumlah investasi dan pada setiap bank perkreditan rakyat adalah sebesar nilaimyang dijamin Lembaga Penjaminan Simpanan (LPS); (b) Investasi dalam bentuk surat berharga dan surat berharga Syariah yang diterbitkan negara atau Bank Indonesia paling tinggi 50\% dari jumlah investasi; (c) Investasi dalam bentuk obligasi dan/atau sukuk korporasi yang masuk peringkat investasi ditetapkan paling tinggi $10 \%$ per penerbit dan seluruhnya paling tinggi $20 \%$ dari jumlah investasi; (d) Investasi dalam bentuk saham yang tercatat di BEI ditetapkan paling tinggi 5\% per emiten dan seluruhnya paling tinggi 20\%; dan (e) Investasi dalam bentuk efek beragun aset yang tercatat di BEI paling tinggi $5 \%$ per manajer investasi dan paling tinggi $20 \%$

\section{PSAK 71: Perubahan pengaturan asset keuangan}

Investasi dalam bentuk asset keuangan menjadi pilihan bagi perusahaan untuk mengelalola keuangannya. Pencatatan dan pelaporan atas transaksi yang terkait aset keuangan diatur dalam PSAK 71 tentang Instrumen Keuangan. PSAK 71 secara umum merupakan pengganti PSAK 55 yang membawa beberapa perubahan utama dalam pencatatan dan pelaporan instrumen keuangan. PSAK 71 merupakan adopsi IFRS 9 Financial Instruments dan efektif mulai berlaku pada tanggal 1 Januari 2020. Namun demikian entitas usaha dapat memilih opsi penerapan dini karena adanya interaksi antara PSAK 71 dan PSAK 72. PSAK 72: Pendapatan dari kontrak dengan pelanggan merupakan standar tunggal untuk pengakuan pendapatan.

Perubahan penting dalam pengaturan instrumen keuangan yang muncul dalam PSAK 71 diantaranya adalah klasifikasi dan pengukuran instrument keuangan, dan penurunan nilai instrument keuangan. PSAK 71 mengatur bahwa klasifikasi instrumen keuangan menggunakan pendekatan analisis model bisnis entitas dalam mengelola instrumen keuangan dan karakteristik arus kas kontraktual dari instrumen keuangan. Analisis dan pengujian dalam mengklasifikasikan instrumen keuangan yang dimiliki meliputi, 1) apakah model bisnis atas kepemilikan instrumen keuangan bertujuan untuk menahan aset keuangan dengan tujuan untuk mengumpulkan arus kas kontraktual, dan 2) apakah dalam persyaratan kontraktual aset keuangan terdapat tanggal tertentu yang memberi kepastian arus kas untuk pembayaran pokok dan bunga atas sejumlah pokok terutang.

Hasil uji pengklasifikasian instumen keuangan tersebut selanjutnya akan menentukan pengukuran instrument keuangan. Terdapat tiga pengukuran instrument keuangan, yaitu (1) instrumen keuangan yang diukur pada laba rugi (FVTPL), (2) instumen keuangan yang diukur melalui penghasilan komprehensif (FVOCI), atau (3) instrumen keuangan yang diukur dengan biaya perolehan yang diamortisasi (amortized cost). Namun demikian apabila terjadi miss 


\section{JURNALKU}

Volume 1 No. 3, September 2021

match accounting, perusahaan dapat mengklasifikasikannya sebagai instrumen keuangan yang diukur dengan opsi nilai wajar (fair value option).

Dalam ketentuannya, PSAK 71 antara lain menyatakan instrument keuangan diukur pada nilai wajar melalui laba rugi kecuali diukur pada biaya perolehan diamortisasi atau nilai wajar melalui penghasilan komprehensif lainnya. Setelah menentukan kriteria pengklasifikasian dan metode pengukurannya, PSAK 71 juga memberi pedoman dalam menentukan cadangan kerugian penurunan nilai dari asset keuangan. PSAK 71 menggunakan metode kredit ekspektasian dalam mengukur kerugian instrument keuangan akibat penurunan nilai instrument keuangan. Pengakuan kerugian kredit dengan metode kerugian kredit ekspektasian, PSAK 71 mensyaratkan adanya pengakuan segera atas dampak perubahan kerugian kredit ekspektasian setelah pengakuan awal asset keuangan. Hal ini berbeda dengan pengaturan dalam PSAK 55 yang mengakui kerugian kredit pada saat peristiwa kerugian kredit terjadi.

Dalam mengakui kerugian kredit segera setelah pengakuan awal, entitas diharuskan untuk untuk mengukur penyisihan kerugian instrument keuangan sejumlah kerugian kredit ekspektasian sepanjang umurnya, jika resiko kredit telah meningkat secara signifikan sejak pengakuan awal. Namun demikian dalam hal risiko kredit instrument keuangan tidak signifikan sejak pengakuan awal, maka entitas cukup mengukur penyisihan kerugian untuk instrument keuangan sejumlah kerugian kredit ekspektasian 12 bulan. Selanjutnya pada setiap tanggal pelaporan entitas bisnis harus mengukur kemungkinan terjadinya peningkatan resiko kredit yang signifikan. Penilaian ini didasarkan pada kemungkinan gagal bayar yang terjadi yaitu dengan membandingkan resiko kredit awal instrument keuangan dengan risiko kredit pada tanggal pelaporan. Dalam pengukuran risiko kredit, PSAK 71 memberi pedoman penggunaan praduga (rebuttable presumption) yaitu, risiko kredit yang signifikan telah terjadi Ketika pembayaran tertunggak lebih dari 30 hari jika tidak ada lagi informasi spesifik lain tentang peminjam, tersedia tanpa biaya dan upaya berlebihan untuk menentukan apakah terdapat kenaikan risiko kredit yang signifikan.

Upaya pengukuran instrument keuangan secara lebih reliable diterapkan melalui pengaturan pengukuran kerugian kredit ekspektasian berbasis perhitungan forward looking. Pada penerapan PSAK 55, pengukuran kerugian kredit berbasis loss incurred, yaitu pertimbangan pengukuran menggunakan data historis masa lalu dan kondisi saat ini. Dalam PSAK 71 ditegaskan bahwa perusahaan dapat mengakui kerugian kredit ekspektasian sepanjang umurnya secara kolektif dengan mempertimbangkan informasi komprehensif yang meliputi informasi tunggakan dan informasi kredit yang relevan seperti kondisi ekonomi makro yang bersifat forward looking. Basis forward looking yang digunakan dalam perhitungan kerugian kredit ekspektasian diharapkan mampu memberikan informasi yang lebih akurat terkait risiko yang dihadapi entitas bisnis atas instrumen keuangan yang dimilikinya. Risiko tersebut kemudian dinotasikan dalam bentuk angka sehingga nilai instrumen keuangan yang dimiliki entitas bisnis akan berpengaruh terhadap nilai bersih instrumen keuangan yang dimilikinya.

Penerapan PSAK 71 terkait kerugian kredit ekspektasian berpotensi menambah beban/kerugian dari entitas bisnis sehingga akan mengurangi nilai keuntungan yang dapat dibukukan. Oleh karena itu, butuh kehati-hatian dari entitas bisnis dalam mempertimbangkan nilai kerugian kredit ekspektasian. Penentuan nilai kerugian kredit ekspektasian membutuhkan banyak informasi dan data agar nilai yang ditetapkan akurat. Beberapa entitas bisnis dalam industri penjaminan mengeluhkan terkait ketersediaan informasi dan data tersebut. Dalam transaksi investasi, informasi/data tersebut bisa diperoleh namun memang membutuhkan usaha bagi entitas bisnis. 


\section{JURNALKU}

Volume 1 No. 3, September 2021

Draf Eksposur (DE) PSAK 71 yang diterbitkan pada tanggal 14 September 2016 mengusulkan 1 Januari 2019 sebagai tanggal efektif dengan pertimbangan bahwa persiapan penerapan telah dilakukan sejak tahun 2014 dengan adanya berbagai aktivitas sosialisasi dan edukasi serta pembentukan kelompok kerja yang beranggotakan dari regulator dan industri perbankan yang diidentifikasi akan terkena dampak yang cukup signifikan dengan penerbitan PSAK 71 ini. Dalam due process procedure penyusunan SAK, DSAK IAI melakukan deliberasi dan mempertimbangkan seluruh masukan dan komentar dari para pemangku kepentingan atas berbagai permasalahan akuntansi yang berkaitan dengan instrumen keuangan termasuk permasalahan kesiapan tanggal efektif penerapannya. Dengan komitmen penuh dari regulator dan industri terdampak untuk membuat action plan agar implementasi PSAK 71 ini dapat berjalan baik dan tepat waktu, maka DSAK IAI memutuskan untuk memberikan kelonggaran tanggal efektif PSAK 71 selama 1 (satu) tahun menjadi 1 Januari 2020. PSAK 71 ini tetap memperkenankan entitas yang ingin menerapkan PSAK 71 ini lebih awal.

\section{Teori Institusional}

Dacin, Goodstein and Scott (2002) menyatakan bahwa salah satu teori yang banyak digunakan dalam memahami perilaku individu dan organisasi adalah teori institusional. Lamers dan Barbour (2006) menggambarkan teori institusional sebagai serangkaian praktik yang dilaksanakan dengan berdasar pada keyakinan rasional yang diformalkan melampaui organisasi dan situasi tertentu. DiMaggio dan Powell (1983) menjelaskan dalam upaya untuk melakukan perubahan dan penyesuaian diri dengan lingkungan, suatu organisasi dapat melakukan tiga mekanisme, yaitu coercive isomorphism, mimetic isomorphism, dan normative isomorphism. Coercive isomorphism merupakan perubahan/penyesuaian diri organisasi sebagai hasil dari tekanan eksternal baik formal maupun informal. Sedangkan perubahan organisasi dengan mimetic isomorphism terjadi karena organisasi meniru organisasi lain karena adanya factor ketidakpastian lingkungan sehingga organisasi mendorong diri mereka untuk menyerupai organisasi lain dalam lingkungan tersebut. Dan pada mekanisme ketiga, organisasi dapat melakukan perubahan karena normative isomorphism, yaitu perubahan yang dilakukan karena ingin menjadi professional dalam bidang tersebut.

Teori institusional menekankan bahwa perubahan karena tekanan eksternal tersebut mendorong organisasi untuk menjadi serupa seiring waktu berjalan (Dimagio dan Powel, 1983). Namun demikian, Scott (2008) menyatakan bahwa organisasi yang awalnya terdorong melakukan perubahan/penyesuaian diri untuk memenuhi kebutuhan dapat terbentur pada keterbatasan organisasi dan lingkungan yang dapat menyebabkan organisasi melakukan tindakan yang menyimpang dari ketentuan yang berlaku. Keputusan organisasi untuk melakukan perubahan/penyesuaian diri atau melakukan perbuatan menyimpang tidak terlepas dari aktor/pelaku dan material pendukung dalam organisasi.

Zilber (2015) menyatakan bahwa terdapat dua faktor yang dapat berpengaruh dalam pengambilan keputusan yaitu symbolic carriers dan material carriers. Scott (2008) menyatakan bahwa symbolic carriers merupakan elemen institusional seperti kepercayaan, norma dan ketentuan yang dapat berdampak pada perilaku sosial. Sementara itu Thornton (2002) mendefinisikan symbolic carriers sebagai regulatory logics yaitu aturan yang dipertimbangkan aktor dalam memutuskan implementasi suatu standar baru. Sementara itu, motif material carriers dijabarkan sebagai hubungan antar aktor, kebiasaan yang menjadi budaya (rutin), dan artifak (Scott, 1995). Lebih lanjut, Scott (2003) mengungkapkan hubungan antar aktor akan menjadi semakin kuat tatkala terdapat suatu komunitas yang memungkinkan para aktor untuk saling berdiskusi dan bertukar ide. Dalam hal aktivitas rutin yang menjadi kebiasaan/budaya, Scott (2003) menyatakan bahwa budaya organisasi terbentuk dari aktivitas rutin yang berpola dan mencerminkan pengetahuan dan pemahaman dari aktor pelaksana. Dan komponen material 


\section{JURNALKU}

Volume 1 No. 3, September 2021

carriers, artifak merupakan suatu wujud budaya yang diciptakan dari kecerdasan manusia dan digunakan untuk membantu melakukan tugasnya (Scott, 2003).

\section{METODE}

Penelitian ini merupakan penelitian kualitatif. Creswell (2016) menyatakan bahwa penelitian kualitatif merupakan penelitian yang mengeksplorasi dan memahami makna dari masalah-masalah sosial pada sejumlah individua tau sekelompok orang. Senada dengan pernyataan tersebut, Mohajan (2018) juga menyatakan bahwa penelitian kualitatif dapat digunakan untuk mengeksplorasi suatu fenomena yang belum pernah dipelajari sebelumnya. Pernyataan lain yang mendukung pendapat-pendapat tersebut dikemukakan Mack et al. (2005) dan Miles dan Huberman (1994) yang menjelaskan bahwa tujuan penelitian kualitatif adalah mengeksplorasi fenomena melalui suatu instrumen yang lebih fleksibel dan menggunakan metode semi terstruktur, seperti wawancara secara mendalam, focus group, dan observasi partisipan.

Dalam penelitian ini, pengumpulan data dilaksanakan melalui metode penyebaran kuesioner kepada 27 perusahaan penjaminan kredit di seluruh Indonesia. Perusahaan Penjaminan kredit di Indonesia terdiri dari 1 perusahaan penjaminan kredit nasional dan 26 perusahaan penjaminan kredit daerah. Selain itu, dalam rangka memperoleh pemahaman informasi yang lebih mendalam dan sarana melakukan triangulasi, atas informasi yang telah diperoleh, dilakukan FGD dalam 4 tahap: (1) FGD dengan PT Jamkrindo; (2) FGD dengan Perusahaan Penjaminan Kredit di seluruh Indonesia dan OJK; (3) FGD dengan Perwakilan Dewan Standar Akuntansi Keuangan; (4) FGD dengan Perwakilan IAPI dan OJK.

Dalam penelitian ini, kuesioner disusun berdasar kerangka teori dan informasi dari hasil observasi awal. Data ini kemudian digunakan untuk menyusun kuesioner yang diberikan kepada para responden. Data kuesioner merupakan data awal untuk mengetahui kesiapan perusahaan penjaminan kredit dalam penerapan PSAK 71. Data awal ini kemudian dikonfirmasi dan diperdalam melalui FGD. Berdasarkan data yang berhasil dikumpulkan melalui kuesioner maupun FGD, dilakukan pengelompokan dan pengorganisasian data ke dalam beberapa kategori. Kategori yang dipergunakan dalam penelitian ini didasarkan pada teori institusional. Pengumpulan data melalui kuesioner dan diperdalam melalui FGD diharapkan dapat memberikan informasi yang solid dan komprehensif. Selain itu FGD yang diselenggarakan dengan melibatkan berbagai pihak yang nantinya terlibat atas penerapan PSAK 71, diharapkan dapat menjadi sarana triangulasi informasi sehingga informasi yang dihasilkan bersifat solid. Hal ini senada dengan pernyataan Denzin dan Lincoln (2005) bahwa triangulasi dilakukan dengan menggunakan beberapa instrument dalam sebuah penelitian.

\section{HASIL DAN PEMBAHASAN \\ Karakter Perusahaan Penjaminan}

Proses penjaminan kredit melibatkan tiga pihak yaitu bank/lembaga keuangan selaku penerima jaminan, debitur seperti UMKM, koperasi, pribadi sebagai terjamin, dan perusahaan penjaminan kredit sebagai pihak penjamin. Dalam prosesnya, calon debitur akan mengajukan kredit modal kerja kepada bank/lembaga keuangan. Atas pengajuan tersebut bank/lembaga keuangan akan melakukan penilaian dan analisa terhadap kelayakan usaha dengan memperhatikan character, capacity, capital, condition dan collateral (5C). Dalam proses ini jika debitur tidak memenuhi persyaratan jaminan maka bank/lembaga keuangan akan mengajukan penjaminan kredit kepada perusahaan penjaminan. Saraswati (2019) menyatakan penjaminan kredit yang diberikan oleh perusahaan penjaminan dilaksanakan melalui 2 (dua) mekanisme, yaitu: 


\section{JURNALKU}

Volume 1 No. 3, September 2021

\section{a). Conditional Automatic Coverage (CAC)}

Dalam mekanisme ini, perusahaan penjaminan akan memberikan penjaminan kredit yang diajukan oleh bank/lembaga keuangan secara langsung tanpa adanya analisa pengajuan. Analisa kelayakan sepenuhnya dilakukan oleh bank/lembaga keuangan. Mekanisme ini biasanya dilakukan dengan memberikan pembatasan plafon kredit pada jumlah tertentu sesuai perjanjian kerjasama antara bank/lembaga keuangan dengan perusahaan penjaminan. Dalam pengajuannya, bank/lembaga keuangan mengajukan penjaminan kredit atas beberapa debitur (lebih dari satu debitur). Dalam mekanisme ini, perusahaan penjaminan tidak mengetahui secara pasti kondisi debitur yang mengajukan penjaminan kredit.

b). Case by Case Coverage (C3)

Dalam mekanisme ini, penjaminan kredit diberikan atas pengajuan penjaminan dengan terlebih dahulu dilakukan penilaian dan analisa kelayakan usaha oleh perusahaan penjaminan. Penjaminan kredit dapat diberikan setelah perusahaan penjaminan menerbitkan Surat Persetujuan Prinsip Penjaminan (SP3). Dalam mekanisme ini, perusahaan penjaminan memberikan penjaminan kredit secara debitur per debitur. Mekanisme ini memungkinkan perusahaan penjaminan untuk mengetahui kondisi debitur yang mengajukan penjaminan kredit

Terlibatnya tiga pihak dalam proses penjaminan kredit, membutuhkan perjanjian yang dapat mengikat secara hukum atas hak dan kewajiban masing-masing pihak yang terlibat. Hubungan antara debitur sebagai terjamin dengan bank/lembaga keuangan sebagai penerima jaminan diikat dalam akad/perjanjian kredit. Sementara itu hubungan antara bank/lembaga keuangan sebagai penerima jaminan dan perusahaan penjaminan kredit sebagai penjamin diikat dalam perjanjian kerjasama.

Peran perusahaan penjaminan muncul dalam hal debitur tidak dapat memenuhi kewajiban finansial sebagaimana disepakati dalam akad/perjanjian kredit (kredit macet). Pada saat terjadi kredit macet, bank/lembaga keuangan menggunakan terlebih dahulu hak klaim kepada perusahaan penjaminan dibanding melakukan eksekusi jaminan dari debitur. Dalam hal perusahaan penjaminan membayar klaim jaminan kredit sebagaimana disepakati dalam perjanjian kerjasama (maksimal $75 \%$ dari kerugian) maka hak tagih bank/lembaga keuangan kepada debitur beralih menjadi hak tagih perusahaan penjaminan kredit. Hal ini sebagaimana dinyatakan dalam Pasal 47 ayat (1) Undang-Undang Nomor 1 Tahun 2016 tentang Penjaminan.

Adanya peralihan hak tagih dari bank/lembaga keuangan kepada perusahaan penjaminan akan memunculkan subrogasi. Perusahaan penjaminan kredit menyebutnya sebagai piutang subrogasi. Mengacu pada KUH Perdata Pasal 1400, subrogasi didefinisikan sebagai penggantian hak-hak si berpiutang oleh seorang pihak ketiga, yang membayar kepada si berpiutang itu, terjadi baik dengan persetujuan maupun demi undang-undang. Namun demikian dalam hal terjadi subrogasi, perusahaan penjamin kredit tidak serta merta melakukan penagihan kewajiban finansial yang harus dibayarkan debitur. Hal ini dilakukan karena adanya keterbatasan sumber daya yang dimiliki oleh perusahaan penjaminan. Selain itu terdapat dasar kuat berupa hubungan hukum yang terjalin antara debitur dan bank/lembaga keuangan. Dengan demikian, penagihan kewajiban finansial debitur tetap dilakukan oleh bank/lembaga keuangan untuk dan mengatasnamakan perusahaan penjaminan kredit. Mekanisme ini sebagaimana disepakati dalam perjanjian kerjasama antara perusahaan penjamin kredit dengan bank/lembaga keuangan.

Dalam proses penagihan kewajiban finansial tersebut dilakukan upaya-upaya seperti rescheduling, reconditioning maupun restructuring (Saraswati, 2019). Rescheduling merupakan perubahan syarat kredit seperti jadwal pembayaran, jangka waktu pembayaran maupun jumlah/besaran angsuran. Reconditioning dilakukan antara lain dengan menurunkan suku bunga kredit. Sementara itu restructuring dilakukan dengan melakukan penataan kembali 


\section{JURNALKU}

Volume 1 No. 3, September 2021

kewajiban finansial melalui penambahan kredit modal bagi debitur (merubah besaran kewajiban finansial debitur).

Namun demikian, dalam hal upaya-upaya tersebut tetap tidak dapat memenuhi kewajiban finansial debitur, maka dilakukan eksekusi agunan. Dalam hal ini eksekusi jaminan dilakukan oleh bank/lembaga keuangan dengan cara menjual seluruh agunan yang dijaminkan debitur. Hasil penjualan tersebut digunakan untuk melunasi utang debitur. Perusahaan penjamin yang telah membayar klaim yang diajukan bank/lembaga keuangan akan menerima sejumlah penggantian (75\% dari kerugian) sebagaimana disepakati dalam perjanjian kerjasama. Apabila terdapat nilai lebih dari penjualan agunan tersebut setelah digunakan untuk pembayaran utang maka nilai tersebut akan dikembalikan kepada debitur.

Aset didefnisikan sebagai sumber daya ekonomi kini yang dikendalikan perusahaan sebagai akibat peristiwa yang lalu dan dapat mendatangkan economic benefit pada masa yang akan datang. Dalam hal ini perpindahan hak tagih kepada perusahaan penjaminan dapat mendatangkan economic benefit bagi perusahaan. Dengan demikian dalam transaksi ini perusahaan akan mencatat piutang subrogasi. Namun demikian, Kustiani dan Mahrus (2020) menyatakan pada praktiknya perusahaan penjaminan tidak melakukan pencatatan piutang subrogasi dalam laporan keuangan (off balance sheet). Lebih lanjut dinyatakan pencatatan baru dilakukan oleh perusahaan penjaminan pada saat perusahaan berhasil menagih dengan mencatat pendapatan subrogasi pada sisi kredit dan kas pada sisi debit.

Berdasarkan informasi yang diperoleh dalam pelaksanan FGD pada penelitian ini, perusahaan penjaminan tidak melakukan pencatatan piutang subrogasi karena tingkat ketertagihan subrogasi yang kecil. Hal ini terjadi mengingat nasabah perusahaan penjaminan adalah usaha kecil, perorangan maupun koperasi yang memiliki resiko tinggi terhadap kebangkrutan ataupun mortalitas. Selain itu bank/lembaga keuangan mengajukan klaim pada saat telah terjadi kredit macet (nasabah tidak mampu membayar) dan tidak ada agunan yang diserahkan pada saat pinjaman diajukan. Selain itu proses penagihan piutang yang dilakukan bank/lembaga keuangan (penerima jaminan) juga turut melemahkan pengendalian subrogasi bagi perusahaan penjamin.

Dalam risetnya, Kustiani dan Mahrus (2020) juga menyatakan bahwa pencatatan piutang subrogasi dengan tingkat ketertagihan kecil dapat mengakibatkan pencatatan cadangan yang besar. Pencatatan cadangan piutang dalam jumlah besar dapat mengakibatkan pencatatan beban yang besar dan berdampak pada turunnya laba perusahaan. Hal ini dapat membawa dampak buruk terhadap penilaian kinerja perusahaan.

Besarnya risiko ketidaktertagihan piutang subrogasi menjadi satu pertimbangan dalam mengakui subrogasi sebagai asset. Hal ini sesuai dengan definisi asset dalam revisi Kerangka Konseptual Pelaporan Keuangan yang menyatakan bahwa asset merupakan sumber daya ekonomi kini yang dihasilkan dari peristiwa masa lalu. Dengan demikian asset dapat diakui jika terdapat hak, potensi untuk menghasilkan manfaat ekonomi serta adanya pengendalian. Namun piutang subrogasi memiliki potensi besar ketidaktertagihan sehingga tidak dapat diharapkan manfaat ekonominya di masa mendatang. Hal inilah yang kemudian menjadi alasan perusahaan penjaminan tidak mencatat piutang subrogasi karena tidak dapat memenuhi definisi asset.

\section{Perubahan Pencatatan Investasi berdasar PSAK 71}

Pada sisi pengelolaan investasi berupa asset-aset keuangan, penerapan PSAK 71 memberikan pedoman perubahan cara mencatat dan menyajikan transaksi yang terkait asset keuangan. Beberapa perubahan utama yang terkandung dalam PSAK 71 sebagai pengganti PSAK 55 dapat diuraikan sebagai berikut.

Pertama, penentuan klasifikasi asset dan liabilitas keuangan yang semula berdasar intensi entitas berubah menggunakan model bisnis dan Solely Payment Principal and Interest (SPPI) test. Dalam menentukan klasifikasi aset dan liabilitas keuangan, entitas harus menguji 


\section{JURNALKU}

Volume 1 No. 3, September 2021

apakah aset/liabilitas tersebut menghasilkan pembayaran secara periodik serta model bisnis nya apak untuk diperjualbelikan atau ditahan. Kedua, klasifikasi aset keuangan berupa utang yang semula diklasifikasikan sebagai Fair Value Through Profit or Loss (FVTPL), Available for Sale (AFS), Loan and Receivable, dan Held to maturity (HTM) berubah menjadi FVTPL, Fair Value Through Other Comprehensive Income (FVOCI) dan amortized Cost. Ketiga, klasifikasi aset keuangan berupa saham yang semula diklasifikasikan FVTPL dan AFS menjadi FVTPL dan FVOCI. Keempat, klasifikasi liabilitas keuangan yang semula FVTPL dan liabilitas lain berubah menjadi FVTPL dan Amortized Cost. Kelima, reklasifikasi aset keuangan berubah yang tadinya diperbolehkan untuk kondisi tertentu menjadi diperbolehkan jika terdapat perubahan model bisnis perusahaan. Keenam, tainting rules yang sebelumnya berlaku untuk reklasifikasi kategori HTM ke AFS yang melebihi batas material berubah menjadi dihapuskan.

Pendekatan penurunan nilai yang semula menggunakan incurred loss berubah menjadi expected credit loss. Pendekatan Expected Credit Loss (ECL) mewajibkan entitas menilai risiko keuangan sejak pengakuan awal menggunakan informasi forward looking seperti proyeksi pertumbuhan ekonomi, tingkat pengangguran, dan indeks harga komoditas pada setiap tanggal pelaporan.

Pembentukan CKPN yang sebelumnya memerlukan bukti obyektif atas penurunan nilai tersebut, berubah menjadi tidak diperlukannya lagi bukti obyektif atas penurunan nilai dengan mempertimbangkan bahwa risiko kolektibilitas merupakan risiko inheren yang melekat pada asset keuangan. PSAK 71 Paragraf 5.5.17 menyatakan entitas dapat mengukur ECL dari instrument keuangan menggunakan rata-rata probabilitas tertimbang melalui evaluasi serangkaian kemungkinan yang dapat terjadi. Selain itu pengukuran juga mempertimbangkan nilai waktu uang dan informasi yang wajar mengenai peristiwa masa lalu, kondisi kini dan perkiraan kondisi ekonomi pada masa depan. Expected Credit Loss (ECL) dapat diukur dengan menggunakan formula berikut:

\section{ECL = EAD x LGD $\times$ PD}

Keterangan:

ECL: Expected Credit Loss

EAD: Exposure at Default

LGD: Loss Given Default

PD: Probability of Default

Dalam pendekatan expected credit loss (ECL), entitas diharapkan dapat membuat estimasi terbaik atas kerugian penurunan nilai yang diharapkan. Dalam formula ini, EAD merupakan jumlah uang yang diinvestasikan pada instrument keuangan (asset keuangan) yang terpapar resiko kredit (credit exposure). Sementara itu LGD merupakan bagian asset keuangan yang akan hilang apabila peminjam gagal bayar. Nilai LGD berbanding terbalik dengan Recovery Return (RR) yang dihitung dengan rumus 1-LGD. Dalam formula ECL juga memasukkan nilai PD yaitu kemungkinan debitur gagal bayar hutang secara tepat waktu selama periode tertentu (biasanya 12 bulan). Dalam formula ECL nilai PD ditentukan dari resiko debitur, yaitu jika terdapat kenaikan resiko kredit maka digunakan PD selama sisa masa pinjaman (PD lifetime), namun jika tidak terdapat kenaikan resiko kredit maka cukup digunakan PD utuk 12 bulan (PD 12 month).

Pendekatan ECL bertujuan untuk menyediakan informasi yang relevan dan real time sebagai dasar pengambilan keputusan. Pendekatan ECL dalam PSAK 71 mewajibkan entitas untuk mengakui dan memperbarui risiko aset-aset keuangan dari awal pengakuan hingga jatuh tempo. Dalam rentang waktu tersebut, jika terdapat peningkatan risiko gagal bayar debitur, entitas juga harus melakukan penyesuaian. Terdapat 3 tahap peningkatan resiko yang dapat diidentifikasi selama rentang waktu pengakuan awal hingga jatuh tempo, yaitu tahap 1 (performing), tahap 2 (under-performing), dan tahap 3 (non-performing). Dalam Tahap 1, asset 


\section{JURNALKU}

Volume 1 No. 3, September 2021

keuangan tidak mengalami peningkatan resiko keuangan sehingga ECL diperhitungkan dalam jangka waktu 12 bulan. Pada Tahap 2, terdapat peningkatan resiko asset keuangan sebagai contoh pinjaman terlambat pembayarannya selama $>30$ hari namun belum masuk Tahap 3 . Dalam hal asset keuangan berada pada tahap 2, ECL diperhitungkan hingga waktu jatuh tempo (lifetime). Sedangkan pada tahap 3, asset keuangan mengalami penurunan nilai yang tajam dan disertai keterlambatan pembayaran. Pada Tahap 3 ini ECL juga harus diperhitungkan hingga waktu jatuh tempo (lifetime).

\section{Penerapan PSAK 71: Kesiapan Perusahaan Penjaminan}

Berbagai perubahan pengaturan terkait asset dan liabilitas keuangan tersebut memaksa entitas untuk melakukan perubahan pencatatan serta penyajian asset dan liabilitas keuangannya. Arifullah dan Firmansyah (2021) dalam hasil penelitiannya menyatakan bahwa sektor perbankan melakukan pengembangan system yang akan dipergunakan dalam rangka penghitungan Cadangan Kerugian Penurunan Nilai (CKPN). Berbagai rapat dan diskusi juga dilakukan guna membahas prinsip, praktek, dan dampak yang terjadi atas implementasi PSAK 71. Chandra (2021) dalam hasil penelitiannya menyatakan bahwa terdapat peningkatan CKPN pada bank domestik setelah penerapan PSAK 71. Penelitian ini menggunakan CKPN diskresioner (estimasi menggunakan data nilai outstanding loan dan non-performing loan) sebagai data CKPN setelah penerapan PSAK 71. Namun demikian hasil penelitian juga menyimpulkan bahwa peningkatan CKPN tidak terjadi pada bank asing.

Sementara itu Azis (2021) dalam penelitiannya menyebutkan, Bank BTN Syariah Malang belum menerapkan PSAK 71 dalam pelaporan keuangannya. Studi ini dilaksanakan melalui wawancara dengan periode pengumpulan data bulan Januari-April 2021. Rizal dan Shauki (2019) dalam penelitiannya menyatakan bahwa beberapa bank dengan kepemilikan pemerintah, asing dan campuran melakukan penerapan dini atas PSAK 71. Pada penelitian ini, penerapan dini PSAK 71 didominasi kondisi mimetic dan normative isomorphism yang muncul karena adanya tekanan tuntutan dari professional yang dinilai benar. Selain itu penelitian ini juga mendapatkan hasil bahwa dampak penerapan PSAK 71 terhadap CKPN tidak selalu berdampak negatif tergantung conservatism penerapan PSAK sebelumnya. Namun demikian, Yusdika dan Purwanti (2021) dalam hasil penelitiannya menyatakan bahwa penerapan PSAK 71 secara signifikan berpengaruh terhadap peningkatan CKPN di sektor perbankan.

Berbagai hasil penelitian tersebut memberi gambaran dampak penerapan PSAK 71 terhadap sector perbankan baik persiapan maupun dampak setelah penerapan. PSAK 71 yang memberikan pengaturan baru atas pencatatan instrument keuangan berpotensi membawa dampak paling besar terhadap sector yang melakukan pengelolaan instrument keuangan seperti perbankan dan Lembaga keuangan. Perusahaan penjaminan kredit juga merupakan entitas yang banyak mengelola instrument keuangan sehingga berpotensi terdampak penerapan PSAK 71. Berdasarkan hasil kuesioner terhadap 26 perusahaan penjaminan kredit daerah dan 1 perusahaan penjaminan kredit nasional, tidak terdapat satupun perusahaan penjaminan kredit yang melakukan penerapan dini PSAK 71. Dari jumlah tersebut 3 perusahaan telah menerapkan PSAK 71 pada tahun 2020 selebihnya 9 dalam tahap persiapan penerapan dan 15 sisanya belum menerapkan sama sekali. Tiga perusahaan penjaminan kredit yang telah menerapkan tersebut yaitu PT Jamkrindo, PT Jamkrida Jateng dan PT Jamkrida Babel. Ketiga perusahaan tersebut menerapkan PSAK 71 sebagai upaya menaati ketentuan Dewan Standar Akuntansi Keuangan maupun Otoritas Jasa Keuangan.

Pada bagian ini tiga perusahaan yang telah menerapkan PSAK 71 dapat dikategorikan melakukan perubahan/penyesuaian diri karena keinginan untuk tampil professional (normative isomorphism). Hal ini terkonfirmasi oleh pernyataan PT Jamkrindo bahwa penerapan PSAK 71 secara retrospektif dilakukan untuk memenuhi ketentuan DSAK IAI. Namun selain itu, pada saat yang bersamaan PT Jamkrindo juga memantapkan diri menjadi anggota holding asuransi 


\section{JURNALKU}

Volume 1 No. 3, September 2021

dan penjaminan dengan induk holding PT Bahana Pembinaan Usaha Indonesia (Persero) atau Indonesia Financial Group (IFG). Langkah PT Jamkrindo bergabung dalam holding asuransi dan penjaminan mengharuskan PT Jamkrindo membenahi laporan keuangannya termasuk penerapan PSAK 71. Namun demikian, penerapan PSAK 71 pada PT Jamkrida Jateng dan PT Jamkrida Babel juga didorong oleh keinginan untuk dapat menampilkan performa yang baik dengan menerapkan PSAK 71 sesuai penetapan DSAK IAI. Sementara itu 9 perusahaan penjaminan yang masih dalam persiapan penerapan PSAK 71 bisa dikategorikan sebagai perubahan yang didorong oleh coercive isomorphism, yakni berubah dalam upaya untuk mengikuti ketentuan DSAK IAI. Dan 15 perusahaan penjaminan kredit yang belum menerapkan PSAK 71 sama sekali meskipun tidak ada intensi untuk melakukan tindakan yang menyimpang (decoupling) namun keterbatasan pemahaman dan sumber daya mendorong perusahaan untuk wait and see.

Hal tersebut terkonfirmasi dalam pertanyaan kuesioner berikutnya terkait alasan menerapkan atau tidak menerapkannya PSAK 71. Dalam kuesioner yang disampaikan kepada para responden dalam penelitian ini, 8 responden menyatakan belum memahami PSAK 71 diidentifikasi sebagai perwakilan peusahaan penjaminan kredit yang belum menerapkan PSAK 71. Secara keseluruhan 15 perusahaan yang belum menerapkan PSAK 71 baik sudah memahami maupun belum memahami PSAK 71 berpendapat bahwa perusahaan belum menerapkan PSAK 71 karena belum adanya aturan dari OJK. Perbedaan pemahaman PSAK 71 yang terjadi pada perusahaan penjaminan kredit yang belum menerapkan PSAK 71 menjadi gambaran bagaimana perusahaan memiliki sikap yang berbeda terhadap perubahan. Dalam FGD terkonfirmasi, beberapa perusahaan penjaminan kredit, meski belum menerapkan PSAK 71 namun telah melakukan berbagai diskusi terkait PSAK 71. Pada beberapa perusahaan lain, ada yang sudah melakukan diskusi namun demikian masih menunggu aturan resmi dari OJK. Dengan demikian perbedaan kebiasaan (rutin) yang kemudian menjadi budaya perusahaan dapat berpengaruh terhadap sikap perusahaan dalam mengalami perubahan, dalam hal uni penerapan PSAK 71. Selain itu, banyaknya perusahaan yang belum menerapkan PSAK 71 karena menunggu aturan OJK sekaligus menjadi konfirmasi bahwa perusahaan penjaminan kredit yang telah menerapkan PSAK 71 melakukan perubahan karena dorongan profesionalime (normative isomorphism).

Alasan lain yang dikemukakan perusahaan penjaminan kredit terkait belum diterapkannya PSAK 71 adalah belum adanya system infrastruktur yang memadai untuk menerapkan PSAK 71 serta belum dikembangkannya model untuk menentukan CKPN. Sistem infrastruktur diharapkan bisa memudahkan perusahaan mengelola investasinya serta menyediakan sarana yang memadai dalam pengukuran nilai investasi sesuai PSAK 71. Modelling untuk menentukan CKPN juga harus dikembangkan oleh perusahaan penjaminan kredit. Pengembangan modelling ini penting bagi perusahaan karena profil resiko yang diambil masing-masing perusahaan berbeda. Pada periode sebelumnya penentuan CKPN merujuk pada aturan OJK dan nilai CKPN yang ditentukan pada umumnya sudah mencukupi meski terdapat 2 perusahaan yang menyatakan nilai CKPN belum mencukupi. Perubahan utama pencatatan investasi dalam PSAK 71 dimaksudkan agar entitas bisnis dapat menyajikan nilai investasi sewajarnya dengan mempertimbangkan resiko pada masa mendatang. Dengan demikian penetapan CKPN yang tidak mencukupi nilainya pada perusahaan penjaminan kredit dapat dihindari.

Pengembangan modelling penentuan CKPN ini juga masih menjadi kendala bagi perusahaan yang telah menerapkan PSAK 71. Berdasarkan hasil kuesioner, dari tiga perusahaan yang telah menerapkan PSAK 71 pada tahun 2020, terdapat 1 perusahaan yang belum mengembangkan model perhitungan ECL. Dua perusahaan lainnya telah mengembangkan model perhitungan ECL, dengan rincian 1 perusahaan menggunakan saldo utang nasabah dan 


\section{JURNALKU}

Volume 1 No. 3, September 2021

1 perusahaan lain menggunakan probability of default sebagai variabel penghitungan ECL. Secara keseluruhan, berdasarkan hasil kuesioner perusahaan penjaminan kredit menganggap pengembangan model CKPN menjadi hambatan besar dalam menerapkan PSAK 71. Dengan demikian, sistem infrastruktur dan pengembangan model penentuan CKPN menjadi artifak yang dapat berpengaruh bagi faktor pelaksana untuk melakukan perubahan. Dengan demikian material carriers berperan signifikan bagi perusahaan penjaminan kredit dalam memutuskan untuk menunda penerapan PSAK 71.

Di sisi lain, peran komunitas dalam membuka hubungan antara aktor pelaku cukup terlihat pada saat dilaksanakan FGD persiapan penerapan PSAK 71 pada perusahaan penjaminan kredit yang dihadiri oleh perusahaan penjaminan kredit baik nasional maupun daerah, Otoritas Jasa Keuangan, Asosiasi Perusahaan Penjaminan Indonesia (Asippindo). Dalam FGD tersebut, dipaparkan aturan baru pengelolaan instrumen keuangan berdasarkan PSAK 71 yang harus dipedomani oleh perusahaan. Pemaparan terkait perubahan klasifikasi dan prosedur penentuan klasifikasi asset keuangan cenderung disetujui oleh seluruh partisipan yang hadir. Namun demikian dalam pemaparan perhitungan cadangan kerugian penurunan nilai, partisipan sangat aktif berdiskusi dan beranggapan metode ECL dalam penentuan CKPN cenderung sulit untuk diterapkan terutama pada perusahaan penjaminan kredit daerah. Pernyataan ini sekaligus mengkonfirmasi bahwa artifak (material carriers) merupakan salah satu kendala bagi perusahaan penjaminan kredit dalam menerapkan PSAK 71. Kesulitan yang dialami dalam pengembangan model ECL diantaranya karena perusahaan penjaminan kredit merasa kesulitan untuk mendapatkan data-data kondisi pada masa yang akan datang terutama dikaitkan dengan data outstanding kredit dan probability default-nya. Pada akhir sesi, perwakilan perusahaan penjaminan kredit meminta agar OJK segera membuat panduan penerapan PSAK 71 untuk perusahaan penjaminan kredit. Selain itu perusahaan penjaminan kredit juga meminta agar dalam pengaturan tersebut terdapat aturan yang jelas terkait waktu penerapan dan prosedur peralihan penerapan PSAK. Hal ini menegaskan bahwa komunitas (ASippindo) masih melakukan upaya terbatas dan masih menunggu aturan/arahan OJK dalam upayanya untuk membersamai perusahaan penjaminan kredit mempersiapkan penerapan PSAK 71.

Sebagai bentuk triangulasi validitas informasi, diselenggarakan pula FGD terbatas dengan mengundang PT Jamkrindo dan PT Jamkrida Jabar dalam waktu yang berbeda. FGD yang dilakukan dengan mengundang PT Jamkrindo dimaksudkan untuk memperoleh gambaran perusahaan penjaminan kredit yang telah menerapkan PSAK 71. Dalam FGD tersebut diperoleh informasi bahwa PT Jamkrindo telah menerapkan PSAK 71 pada tahun 2020 dan tidak mengalami hambatan yang berarti. Dalam hal perubahan klasifikasi, PT Jamkrindo telah dapat melaksanakan dengan baik. Namun demikian, PT Jamkrindo masih mengembangkan model ECL yang tepat untuk dapat dipergunakan dalam perhitungan CKPN. Dalam penerapan PSAK 71, PT Jamkrindo menerapkan retrospektif dalam peralihan/perubahan PSAK 55 menjadi PSAK 71. Hal ini dilakukan bersamaan dengan perubahan PT Jamkrindo (Persero) menjadi PT Jamkrindo sebagai bagian dari holding IFG. Sementara itu dalam FGD yang diselenggarakan dengan mengundang PT Jamkrida Jabar, diperoleh informasi bahwa PT Jamkrida Jabar masih menunggu aturan dari OJK terkait penerapan PSAK 71. Kendala seperti penentuan model dalam menghitung CKPN berbasis ECL juga masih ditemui pada PT Jamkrida Jabar.

Selain 3 FGD tersebut, dalam penelitian ini juga diselenggarakan FGD dengan mengundang Ikatan Akuntan Publik Indonesia. FGD ini diselenggarakan untuk mendapatkan pemahaman yang selaras antara pelaku usaha, IAPI sebagai perwakilan auditor dan OJK sebagai regulator. Dalam FGD ini, isu klasifikasi juga tidak mengemuka. Isu terkait model ECL masih menjadi diskusi meski berakhir dengan sebuah kesepahaman. Dan pada akhir sesi, IAPI sebagai perwakilan auditor juga meminta kepada OJK untuk menetapkan aturan jelas terkait 


\section{JURNALKU}

Volume 1 No. 3, September 2021

penerapan PSAK 71. Aturan OJK atas penerapan PSAK 71 tersebut juga tidak boleh bertentangan dengan pedoman yang telah diterapkan DSAK melalui PSAK 71.

\section{PENUTUP}

\section{Simpulan}

Hasil penelitian ini menunjukkan bahwa dari 27 perusahaan penjaminan kredit yang menjadi responden, 3 perusahan telah menerapkan PSAK 71 pada tahun 2020. Sebanyak 9 perusahaan lainnya masih dalam persiapan dan 15 perusahaan sisanya belum menerapkan PSAK 71 pada tahun 2020. Berdasarkan hasil pengamatan, 3 perusahaan penjaminan kredit menerapkan PSAK 71 karena dorongan profesionalisme (normative isomorphism). Meski DSAK IAI menyatakan PSAK 71 efektif berlaku pada tahun 2020 namun Sebagian besar perusahaan penjaminan kredit masih menunggu aturan OJK. Sikap 7 perusahaan penjaminan kredit lain yang meski telah memahami namun belum menerapkan PSAK 71 bisa dikategorikan sebagai mimetic isomorphism karena masih wait and see. Sementara 9 perusahaan penjaminan kredit lainnya yang telah masuk di persiapan menyadari bahwa tekanan dari eksternal untuk segera menerapkan PSAK 71 telah ada (coercive isomorphism), namun kendala seperti belum adanya pengembangan model ECL menjadi hambatan signifikan utuk melangkah pada penerapan PSAK 71.

Pada tahapan selanjutnya, penelitian ini dapat mengidentifikasi bahwa material carriers artifak berperan besar bagi faktor pelaksana dalam menerapkan PSAK 71. Belum adanya model penentuan CKPN dan sistem infrastruktur yang memadai mendorong perusahaan penjaminan untuk menahan diri dari penerapan PSAK 71. Dalam material carriers, hubungan antar faktor yang difasilitasi oleh komunitas juga berperan untu memberi dorongan penerapan PSAK 71. Asippindo sebagai komunitas perusahaan penjaminan kredit menjadi fasilitator bagi perusahaan penjaminan untuk melakukan diskusi dan pertukaran ide terkait penerapan PSAK 71. Meski pada saat penelitian ini dilaksanakan, peran Asipindo masih terbatas terkait persiapan penerapan PSAK 71. Keterbatasan peran Asippindo tidak terlepas dari kepercayaan untuk menunggu aturan/arahan dari OJK yang dalam hal ini berperan sebagai pengawas dan regulator. Saran

Penelitian ini memberi implikasi bahwa perusahaan penjaminan kredit daerah membutuhkan sebuah kepastian aturan dan komunitas yang solid untuk menghadapi perubahan. Penerapan PSAK 71 yang berpotensi memberikan dampak besar bagi lembaga keuangan terutama besaran CKPN, mendorong sebagian besar perusahaan penjaminan untuk bersikap wait and see. Penguatan peran komunitas sebagai wadah untuk berdiskusi dan bertukar pandangan menjadi sangat krusial untuk memantapkan aktor pelaksana dalam mengambil keputusan. Penelitian ini memiliki keterbatasan pada fokus penelitian yang dibatasi pada perusahaan penjaminan kredit. Penelitian belum melakukan upaya untuk mendapatkan informasi terkait forum-forum yang diselenggarakan Asippindo dalam membersamai perusahaan penjaminan melakukan persiapan penerapan PSAK 71. Pada penelitian selanjutnya dapat diperluas kepada peran komunitas, dalam hal ini Asippindo, dalam mendukung kesiapan industri menghadapi perubahan. Penelitian juga dapat diperluas kepada sektor lain yang terdampak atas penerapan PSAK 71.

\section{DAFTAR PUSTAKA}

Aziz, Z. M. I., Afifudin, A., \& Sari, A. F. K. (2021). Analisa Penerapan PSAK 71 Pada Perbankan Syariah (Studi Kasus Pada Bank BTN Syariah Kota Malang). Jurnal Ilmiah Riset Akuntansi, 10(12). 


\section{JURNALKU}

Volume 1 No. 3, September 2021

Chandra, H. W. (2021). Dampak Penerapan Metode Kerugian Kredit Ekspektasian Sesuai Dengan PSAK 71 Terhadap Diskresi Akrual Cadangan Kerugian Penurunan Nilai Pada Entitas Perbankan.

Cahyono, A. T. (2011). Meta Teori Standar Akuntansi Keuangan Di Indonesia-Menuju Konvergensi SAK Di Masa Globalisasi. Jurnal Eksis, 7(2), 1884-1897.

Creswell, J.W. 2013. Research Design: Qualitative, Quantitative, and Mixed Methods Approaches. SAGE Publications.

Dacin, M. T., Goodstein, J., \& Scott, W. R. (2002. Institutional theory and institutional change: introduction to the special research forum. The Academy of Management Journal, 45(1), 44-55.

Denzin, N. K., and Y. S. Lincoln. 2005. The SAGE Handbook of Qualitative Research (3rd ed.). Thousand Oaks: Sage Publications.

DiMaggio, P. J., \& Powell, W. W. (1983). The iron cage revisited institutional isomorphism and collective rationality in organizational fields.American Sociological Review, 48(2), 147-160. Retrieved from http://www.jstor.org/stable/2095101

Firmansyah, A., \& Arifullah, M. N. (2021). Pencadangan Piutang Pada Perusahaan Sub Sektor Perbankan Di Indonesia: Dampak Penerapan PSAK 71. Current: Jurnal Kajian Akuntansi Dan Bisnis Terkini, 2(1), 122-142.

Francis, J., Lafond, R., Olsson, P. M., Dan Schipper, K. (2004). Costs Of Equity And Earnings Attributes. The Accounting Review, 79(4): 967-1010.

Kustiani, N. A., Mahrus, M. L., \& Prabowo, M. (2020). Analisis Pencatatan Piutang Subrogasi Pada Perusahaan Penjaminan. Jurnal Riset Terapan Akuntansi, 4(1), 32-48.

Lammers, J., and J. Barbour. 2006. An Institutional Theory of Organizational Communication. Communication Theory, 16, 356 - 377.

Mack, N. (2005). Qualitative research methods: A data collector's field guide.

Miles, M. B., \& Huberman, A. M. (1994). Qualitative data analysis: An expanded sourcebook. sage.

Mohajan, HK. 2018. Qualitative Research Methodology in Social Sciences and Related Subjects. Journal of Economic Development, Environment and People. 7(01): 23-48.

Peraturan Otoritas Jasa Keuangan Nomor 6/POJK.05/2014 Tentang Penyelenggaraan Usaha Lembaga Penjaminan

Rizal, A. P., \& Shauki, E. R. (2019). Motive and obstacles in making a decision as early adopters of PSAK no. 71 for impairment provision of loans (Study case in Indonesia banking industry). AFEBI Accounting Review, 3(02), 13-24.

Rohmah, A., \& Yuni, N. S. (2013). Dampak Penerapan Standar Akuntansi Keuangan (SAK) Pasca Adopsi IFRS Terhadap Relevansi Nilai Dan Asimetri Informasi. Simposium Nasional Akuntansi XVI Manado.

Santoso, A. B. (2013). Pengaruh Kualitas Pelaporan Keuangan Terhadap Asimetri Informasi Dengan Ukuran Perusahaan Sebagai Pemoderasi Pada Perusahaan Manufaktur Di BEI. Jurnal Ilmiah Mahasiswa Akuntansi, 1 (4): 32-37.

Saraswati, L. P. P. S. P., \& Markeling, I. K. Penyelesaian Kredit Macet Terhadap Pelaku UMKM Yang Dijamin Oleh PT Jamkrida Bali Mandara (Studi Pada PT Bank Pembangunan Daerah Bali Kantor Cabang Utama Denpasar).

Scott, W. R. (1995). Institutions and organizations.California, USA: Sage Publications, Inc.

Scott, W. R. (2003). Institutional carriers: reviewing modes of transporting ideas over time and spaceand considering their consequences. Industrial and Corporate Change, 12(4), 879-894. https://doi.org/10.1093/icc/12.4.879

Scott, W. R. 2008. Lords of the Dance: Professionals as Institutional Agents. Sage Publications, 29(2), 21. 


\section{JURNALKU}

Volume 1 No. 3, September 2021

Setiany, E., \& Wulandari, A. (2015). Kualitas Pelaporan Keuangan Dan Asimetri Informasi Di Industri Manufaktur Indonesia. Efektif Jurnal Bisnis Dan Ekonomi, 6(2), 17-24.

Shauki, E. R. (2018). “Converting Your Master/Ph.D. Thesis into a Journal Article” Handout Case Writing and Methodology, ECAM 809303. Universitas Indonesia.

Suroso, S. (2017). Penerapan PSAK 71 Dan Dampaknya Terhadap Kewajiban Penyediaan Modal Minimum Bank. Jurnal Bina Akuntansi, 4(2), 157-165.

Thornton, P. H., \& Ocasio, W. (1999). Institutional logics and the historical contingency of power in organizations: Executive succession in the higher education publishing industry, 1958-1990. American Journal of Sociology, 105(3), 801-843. https://doi.org/10.1086/210361

Yusdika, A. And Purwanti, D. 2021. Implementation Of PSAK 71 Financial Instruments In The Banking Sector During The Covid-19 Pandemic. Riset. 3, 1 (Mar. 2021), 402 - 416. DOI:Https://Doi.Org/10.37641/Riset.V3i1.72.

Zilber, T. B. 2015. Institutional Logics and Institutional Work: Should They Be Agreed? In Research in the Sociology of Organizations, 39.

https://www.antaranews.com/berita/107542/pergantian-nama-menjadi-perum-jaminan-kreditindonesia-jamkrindo

https://tirto.id/bagaimana-psak-71-memengaruhi-perbankan-ehPf\#top

https://keuangan.kontan.co.id/news/psak-71-diterapkan-tahun-depan-jamkrindo-lakukanefisiensi

https://sikapiuangmu.ojk.go.id/FrontEnd/CMS/Article/20617

https://kemenkopukm.go.id/uploads/laporan/1617162002_SANDINGAN_DATA_UMKM_2 018-2019.pdf

https://finansial.bisnis.com/read/20210715/215/1418009/terdampak-ppkm-profitabilitasindustri-penjaminan-kredit-ikut-tertekan

https://www.antaranews.com/berita/107542/pergantian-nama-menjadi-perum-jaminan-kreditindonesia-jamkrindo

https://finansial.bisnis.com/read/20210715/215/1418009/terdampak-ppkm-profitabilitasindustri-penjaminan-kredit-ikut-tertekan

https://www.ruangenergi.com/51-tahun-jamkrindo-kolaboratif-membangun-umkm-dankoperasi-bangkit/

https://setkab.go.id/perusahaan-penjamin-kredit-daerah-untuk-umkm/ 